\title{
Overview of the Rheological Behaviour of Ceramic Slurries
}

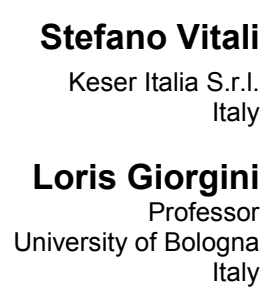

Given that the majority of raw materials used in the ceramic industry have sedimentary origins, their formation is conducted in aqueous medium, reason for which most ceramic production processes involve water for manufacturing diverse semi-finished materials. However, the rheological behaviour inherent of ceramics may infer significant impact on their processing, defining crucial parameters such as solid-to-water ratio, deflocculation level, and tpye and amount of chemical additives to be used. Thus, the present work explores the intricacy of essential aspects of rheology in ceramic slurries, intending to provide an overview of the chemical, physical and practical influence on the manufacturing of tiles from both industrial and scientific points of view.

Keywords: Thixotropy, Clay, Rheology, Zeta potential, Suspension, Dispersion.

\section{INTRODUCTION}

The industry constantly evolves toward the usage of more efficient materials aiming to achieve optimal costbenefit relations and enhanced performance. Within this context, it is imperative to acknowledge the importance held by composite materials [1-5], where ceramics play a major role due to their elevated toughness and environmental resistance. For this reason and to allow a better comprehension of their properties, the analysis of manufacturing steps become essential.

Ceramic slurries formed by mineral grinded powder and water are extensively used in industrial manufacturing techniques such as spray-drying, slip-casting and tape-casting to manufacture diverse products and varieties of tiles. The way of dispersion of such powder on aqueous medium is imperative to understand the expected rheological behavior of the mixture, which basically stands for the flow of matter and how it deforms.

For instance, according to Tsetsekou et al. [3], the particles must have an appropriate settlement rate and be able to remain in suspension to avoid segregation and assure a homogeneous density gradient over the manufactured part. Simultaneously, the slurries should be insensitive to solid content and chemical composition variations as well as storage time.

The importance of having a high enough solid ratio is highlighted by Lange et al. [4], depicting that it is critical for the attainment of adequate casting rates and to minimize the energy consumption demanded by the following step of drying, once the less moisture there is to be removed, the less energy is spent. Lee et al. [5] state that the rheology conditions have utmost influence on the performance quality of the slip for sanitaryware casting, sticking the piece in the mold, causing an

Received: Septeber 2018, Accepted: November 2018

Correspondence to: Stefano Vitali

Keser Italia S.r.1.

Via Marche 5, 41049, Sassuolo, Italy

E-mail: stefano.vitali84@gmail.com

doi: $10.5937 /$ fmet1901042V

(C) Faculty of Mechanical Engineering, Belgrade. All rights reserved improper cast rate, an improper trim quality, soda spots and even a precocious mold release. Consequently, the general resistance properties can be severely affected producing brittle casts [5], which demean important mechanical thresholds for a structural part such as to compression and impact [6].

Tsetsekou et al. [3] analyzed the stabilization of alumina slurries of high solids content by using different types of dispersants, and found out that the slurry solid content increased the density in both green and fired states of the ceramics, decreased the post-firing shrinkage and the products presented enhanced mechanical properties. Souza et al. [7] used humic acid extracted from subbituminous coal [8] as a dispersant in an alumina suspension, finding optimal values of 0.016 $\mathrm{wt} \%$ of humic acid (which is near to the viscosity when using sodium polyacrylate), showing prominent results for slip casting by achieving remarkable colloidal stability and attaining high density parts, attaining high density parts, existance of negative surface charges, absence of metallic complexes in the molecules, and pointing out the alkaline $\mathrm{pH} 11$ as ideal once it allows the humic acid to have an enhanced zeta potential and decreases its turbidity.

The most important parameters to be taken into account for the preparation of an adequate slurry can be summarized as:

- Solid-to-water ratio: also known as specific gravity, it has a prevailing influence on the thixotropy, i.e. the long-term viscosity, defining casting properties of the mix such as casting rate and plasticity of the cast part.

- Types and amount of chemical additives: used to control deffloculation and thixotropy, this resource is able to modify the slip in an economic way, for example diminishing the dispersion when using ball clayis and kaolin in slurry form, and to prevent the concentration of fines in the mold/cast interface.

- Deflocculation level (determined by organic dispersants): influences the plastic characteristics of the slip, being crucial to obtain a homogeneous and 
stable system of non-aggregated particles [9]. Some phosponate-based deffloculants used in ceramic coating can even inhibit the corrosion of pipes [10].

All these factors are separately addressed in the following sessions of the present work, aiming to provide a guideline for the best practices $[11,12]$ and the highest quality for processes and products [13].

\section{INFLUENCE OF WATER}

Clay and water mixtures, if mixed in 5:1 w/w ratio, form a plastic paste; subsequent water additions, in order to achieve $3: 1$ and $1: 1 \mathrm{w} / \mathrm{w}$ ratios, produce colloidal suspensions. Water molecules act like dipoles and therefore exhibit strong electrostatic interactions with clay and kaolin particles [14-16]. Clay/kaolin and water mixtures produce colloidal suspensions with extremely differentiated and complex rheological behaviours defined by a potential. This, called zeta potential " $\zeta$ ", is due to electric field redistribution and produces an electric double layer around suspension particles and its surrounding counter ions (Figure 1).

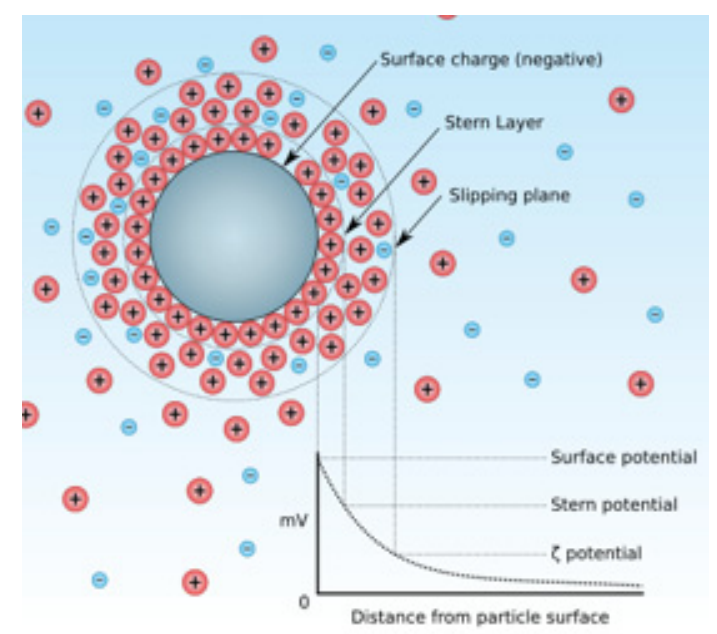

Figure 1. Electric double layer of a dispersion particle and potential graph.

If the absolute value of zeta potential is too low, repulsion forces between particles are not strong enough to overcome the attraction forces of van der Waals and, consequently, they start to cluster into "flakes" causing undesired settlements (instable suspension).

Instead, absolute values of zeta potential prevent particle flocculation and sedimentation (stable suspension) [17-19].

Table 1 summarizes the different stability of colloids according to zeta potential " $\zeta$ " variation $[17,19,20]$ :

Table 1. Colloidal stability as a function of $\zeta$ stability

\begin{tabular}{cc}
\hline Zeta potential " $\zeta "(\mathrm{mV})$ & Colloidal stability \\
\hline From 0 to \pm 5 & Rapid flocculation \\
\hline From \pm 10 to \pm 30 & Incipient instability \\
\hline From \pm 30 to \pm 40 & Moderate stability \\
\hline From \pm 40 to \pm 60 & Good stability \\
\hline$> \pm 61$ & Excellent stability \\
\hline
\end{tabular}

Clay and water mixtures generally exhibit nonNewtonian behaviour [21-22]. In particular, they display plastic behaviour (presence of yield stress) and thixotropic pseudoplastic behaviour (time-dependent shear thinning property). The presence of such phenomena during production phases is undesired and becomes relevant in technological cycles such as grinding, sieving and storage. Zeta potential, cation exchange, surface contact area between solid and liquid particles, the presence of soluble salts in the clay such as sulphates and calcium salts are the main parameters that directly influence clay slurries' rheology. These parameters can be controlled by:

- Percentage of clay in the slurry: increasing solid fraction, clayey systems' thixotropy increases;

- Quantity and type of deflocculant: the most commonly used substances are silicates, phosphates and organic substances;

- Grinding control: as the grinding degree increases, the contact surface available for cation exchange between solid and liquid becomes greater and increases system's temperature with the appearance of thixotropy and yield stress phenomena.

Ceramic slurries are mainly composed of a clayey plastic fraction and an inert-melting fraction based on quartz and feldspar. Bleachers, dyes, recovery materials and dispersants are added to the rest of raw materials and loaded into ball mills (Figure 2) and ground with the right dose of water until pre-set residue is obtained. From the rheological point of view, clayey fraction is responsible for introducing yield stress and high thixotropy to the mixtures. On the contrary, low concentrated water/kaolin systems show newtonian behaviour. Grinding waters contain a soluble fraction composed by $\mathrm{Ca}^{2+}, \mathrm{Mg}^{2+}, \mathrm{Fe}^{2+}, \mathrm{Fe}^{3+}, \mathrm{Al}^{3+}$ and $\mathrm{Zn}^{2+}$ that contribute to the zeta potential decrease and to dispersion instability. Finally, inert-melting fraction exerts a negative effect on rheology due to steric obstruction in a system where electric charges are already present [17].

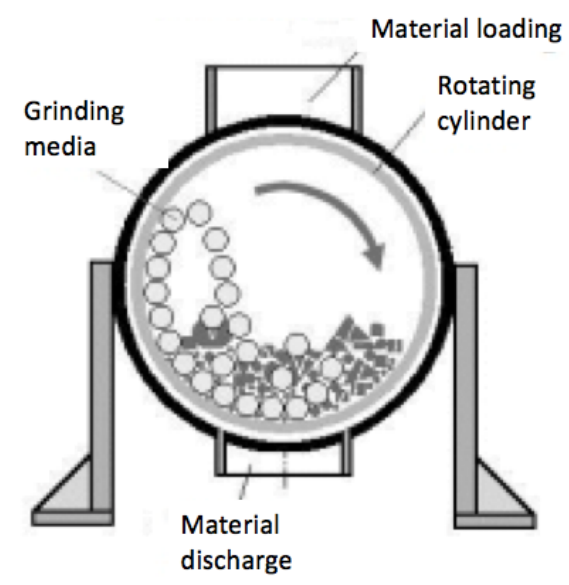

Figure 2. Ceramic ball mill scheme

Grinding water composition represents another important aspect to take in count inside of ceramic plants. The water used in the mills as dispersant of solid fraction (feldspar, clay, kaolin and sand) comes from various industrial sector present inside the plant (e.g. enameling) or from water purification plant and could contain small quantities of various substances that can move the $\mathrm{pH}$ out of the optimal deflocculation range. However, a regular 
check of the main chemical-physical parameters of the grinding water, such as $\mathrm{pH}$, electrical conductivity, total permanent hardness, COD (chemical oxygen demand), allows to avoid unpleasant situations during production without recourse to particular solutions.

\section{RHEOLOGICAL ADDITIVES}

Deflocculating substances are rheological additives widely used in ceramic industry. They are distinguished by their nature, organic and inorganic, and how they express their action: deflocculants, dispersants and fluidizers. "Dispersant" is the liquid phase in which immiscible raw materials, both solid and liquid, are mixed. Generally, water represents the dispersing phase but it's not the rule: several ceramic applications use special vehicles/oils. "Fluidizer" is a substance able to lower a system's viscosity. "Deflocculating substances" have deflocculant action in a suspending medium in order to promote uniform and maximum separation of extremely fine solid particles. Deflocculants represent an effective solution to overcome the rheological problems typical of ceramic suspensions and they are added to a colloidal system in very small amounts $(<1 \% \mathrm{w} / \mathrm{w})$ in order to increase its electrokinetic potential (or zeta potential). These additives are adsorbed on the surface of kaolin/clay particles and introduce steric and/or electrostatic repulsion forces between them [16]. High values of the zeta potential increase the repulsive forces between suspension particles and raise its stability avoiding sedimentation $[17,19,20]$.

Rheological additives are able to decrease remarkably slurries' viscosity and, therefore, they act as fluidizers. Nevertheless, not all fluidizers are deflocculants. This is the case of CMCs: CMCs can avoid yield stress in certain ceramic suspensions, in particular those affected by the presence of $\mathrm{Ca}^{2+}$ ions. However, with the passing of time, even few hours, they cause the formation of a hard sediment on the vessel's bottom which is particularly complicated to remove through a simple stirring.

This condition is particularly undesirable in the case of slurries stored in slow-stirring tanks.

Deflocculating substances act according the following processes:

- Increase of ceramic pH suspension by adding monovalent bases or basic electrolytes (hydroxide ions);

- Divalent cations replacement with monovalent cations $\left(\mathrm{Na}^{+}, \mathrm{K}^{+}, \mathrm{Li}^{+}, \mathrm{NH}_{4}^{+}\right)$within the electric double layer;

- Anions adsorption on the surface of kaolin or clay particles;

- Elimination of flocculant cations due to lack of solubilization and formation of coordination complexes.

Examples of inorganic deflocculants are sodium carbonate, $\mathrm{Na}_{2} \mathrm{CO}_{3}$ [14]; sodium silicate, $\mathrm{Na}_{2} \mathrm{O} \cdot \mathrm{SiO}_{3}[18,20]$; sodium hexametaphosphate [23], sodium tripoly-phosphate (STPP) [17]; and barium carbonate, $\mathrm{BaCO}_{3}$ [17].

The effect of carbon dispersion on a silicon carbide ceramic as a function of the addition of the right deflocculants was studied by Wang et al. [24], which evaluated its influence on the mechanical properties of tiles, proofing that coupons with substances properly diffused present better mechanical properties for having a more homogeneous surface and presenting less stress concentration zones.

The visual effect of carbon dispersion on silicon carbide coupons as a function of the additives used can be seen in Figure 3:

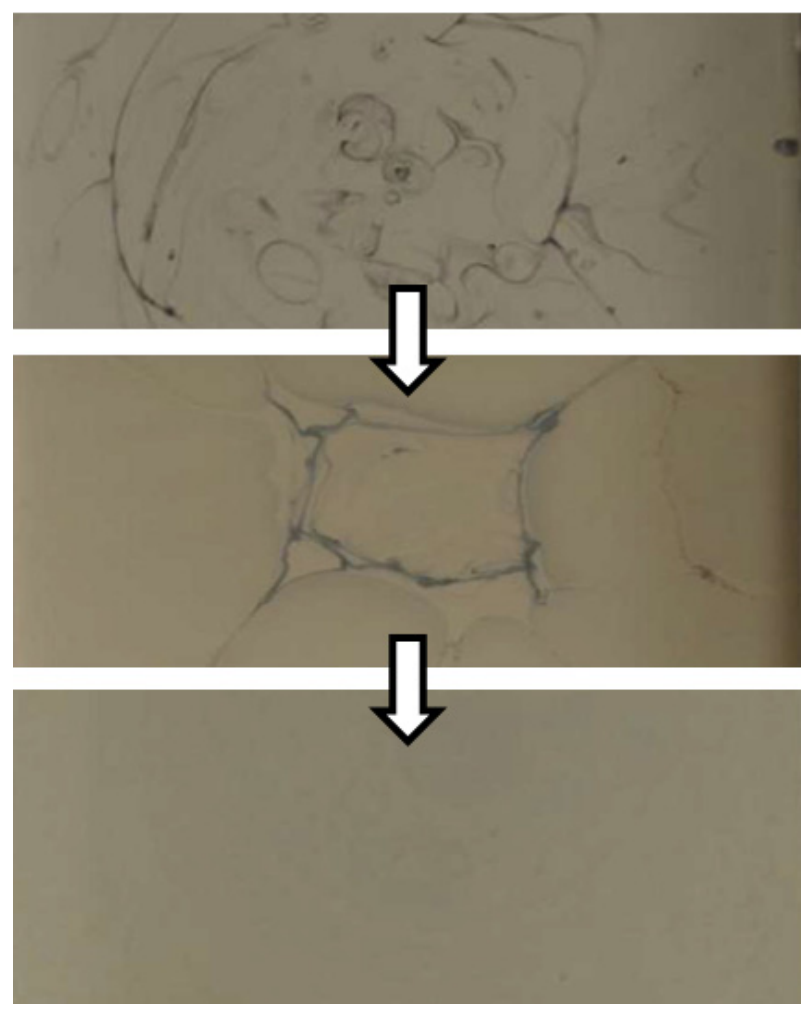

Figure 3. Carbon dispersion when using different chemical additives [24].

Hammadi [25] analyzed chemically, mechanically and rheologically a slip modified by bentonite, and discovered that when the percentage of the aforementioned additive is increased, the base slip makes the mechanical properties to improve (higher yield stress) and causes a rapid density increase as well as previously observed for polymer containing bentonite derivatives [26,27]. Wiecinska et al. [28] studied the effects of organic additives used in the preparation of ceramic components from 3D elements (e.g. gelcasting and UVcuring of the polymer), and found out that the most important parameters to define the elastic behaviour of ceramic thin tapes is the low glass transition temperature $\left(T_{g}\right)$ of the polymer adopted, in the sense that lower the transition temperature is, the better.

This threshold can be lowered with the addition of glycerol or other plasticizers. The article confirms the strong influence that organic additives have over the viscoelastic properties of ceramic slurries.

Sodium carbonate acts as cation exchanger: $\mathrm{Ca}^{2+}$ ions bind the carbonate ion and precipitates as seen in (1):

$$
\text { Clay } \mathrm{Ca}^{2+}+\mathrm{Na}_{2} \mathrm{CO}_{3} \rightarrow \text { Clay } \mathrm{Na}^{2+}+\mathrm{Ca}_{2} \mathrm{CO}_{3} \downarrow
$$

Sodium silicates $\left(\mathrm{Na}_{2} \mathrm{SiO}_{3}\right)$ are among the most used inorganic additives in order to guarantee clay and kaolin suspensions stability either as a single constituent or 
major part of a deflocculating mixture. The mechanisms of action are multiple:

- Replacement of calcium counter ions with $\mathrm{Na}+$ ions within the electrical double layer [15-20];

- $\mathrm{pH}$ increase and consequent raise of anions amount in the mixture;

- Condensation reaction of silanol groups with hydroxyl groups within kaolin particles [19];

- Protective effect of colloidal silica on clay particles contributes to dispersion stability.

Addition of sodium silicate to a clayey-kaolinitic suspension modifies the characteristics of particles' surface and the chemical-physical properties of the mixture ( $\mathrm{pH}$, ionic strength, etc.). Sodium silicate undergoes to hydrolysis reaction in the ceramic slip and makes sodium ions available for deflocculation.

The addition of sodium carbonate to sodium silicate enhances deflocculating effect to the mixture by increasing repulsive forces between particles. In particular, the reaction between silicate anion $\left(\mathrm{SiO}_{3}{ }^{-2}\right)$ and divalent

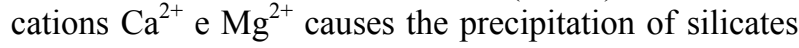
[18].

However, the presence of sulphates, as in the case of englobe slips based on calcium sulfate or gypsum castings, can negatively interfere with their deflocculating power [17].

Sodium hexametaphosphate $\left(\mathrm{NaPO}_{3}\right)_{6}$ [18] and sodium tripolyphosphate [14] (Figure 4) are among the most used phosphate deflocculants in ceramic industry. They exercise their deflocculating power through the following mechanisms: adsorption of phosphate anions on clay particles; as a consequence, the value of negative charge of clay particles increases; formation of insoluble complexes with flocculating cations; and flocculating cations replacement with sodium ions $\left(\mathrm{Na}^{+}\right)$ within the electric double layer.

The above-mentioned processes cause zeta potential decrease of the suspension and, consequently, greater stability of the ceramic slurry [23].

\section{ORGANIC DISPERSANTS}

Organic deflocculants can be either of natural source, like humic acids and tannins [17] or of synthetic derivation, as in the case of carboxymethyl cellulose (CMC), polycarbonates and polyacrylates [18,23]. Humic acids inhibit the action of cations which are responsible of flocculation by creating complexes with clay particles. Tannins are astringent and as polyphenolic compounds are characterized by the presence of several phenolic groups. It is hypothesized that the aromatic part of these molecules is adsorbed by the colloidal particles and this configuration leads the mixtures to lower viscosities.

Sodium polyacrylates are anionic polyelectrolytes that belong to the family of organic dispersants. The negative charges localized on the carboxylic group of the side chain cause dispersant adsorption on the suspended particles; it increases negative charge on particles and therefore its zeta potential value [17].

Generally, polyelectrolytes are more effective than sodium silicate. Organic electrolytes exert their deflocculating power not only lowering van der Waals attraction forces between particles but also providing steric barrier between colloidal particles due to their macromolecular structure $[18,19]$.

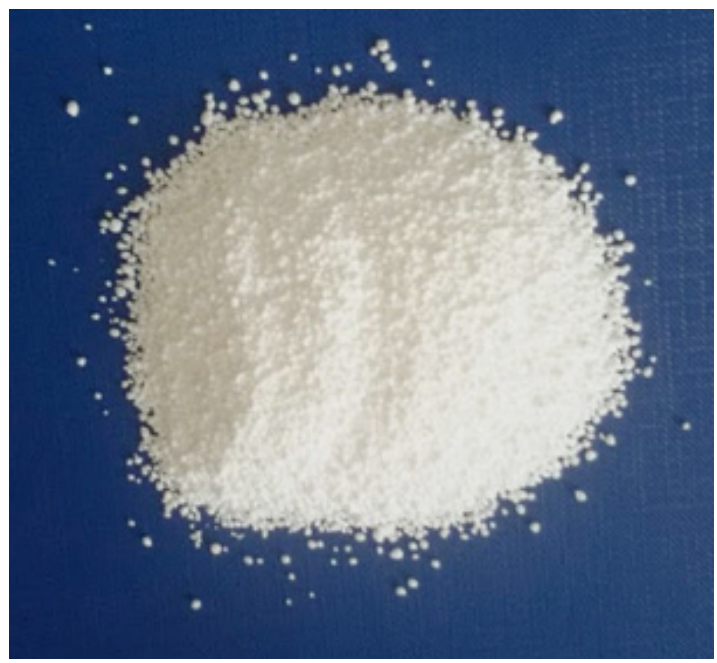

Figure 4. Sodium tripolyphosphate (STPP) sample

Carboxymethyl cellulose (Figure 5, where $\mathrm{R}=\mathrm{H}$ or $\mathrm{CH}_{2} \mathrm{CO}_{2} \mathrm{H}$ ), or $\mathrm{CMC}$, is obtained by reaction of cellulose with alkali and chloroacetic acid. CMC as few other hydrophilic polymers [29], dissolves rapidly in cold water and it is mainly used for controlling viscosity without sol-gel formation.

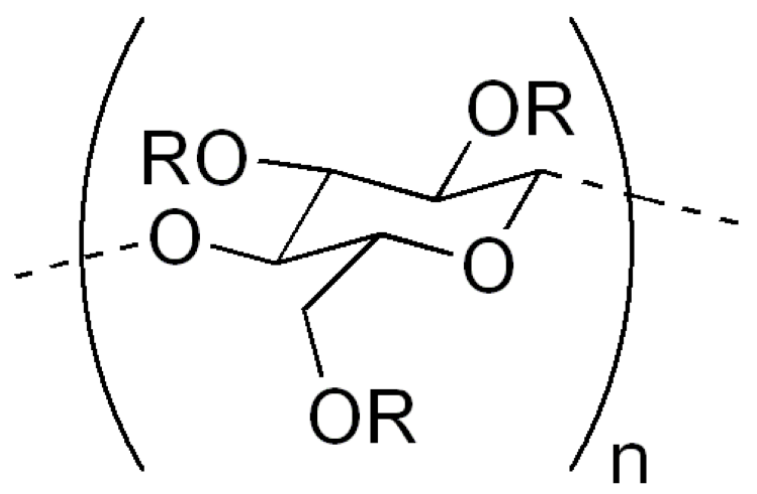

Figure 5. Chemical structure of carboxymethyl cellulose (CMC).

Therefore, CMCs are particularly widespread in the ceramic industry as well. Their deflocculating power is expressed exactly like the other dispersants, increasing the negative charge on clay/kaolin particles and, consequently, raising of the zeta potential absolute value.

CMCs are the widely used as glue for glaze: they improve the unfired strength of ceramic glazes, increasing cohesion of the particles and adhesion to the unfired material. Glaze application is improved as well. $[17,23]$. Nevertheless, due to unclear reasons, CMCs can give instability even in a short time for certain solid fraction typology added to the slip.

\section{CONCLUSION}

The present study aimed at summarizing the main aspects responsible for the rheological behaviour of ceramic slurries that have to be properly addressed in manufacturing ceramics. These topics, namely solid-to- 
water ratio, chemical additives and organic dispersants have been investigated through the literature and showed that they are crucial for determining the outcome quality of the ceramic products in terms of manufacturing defects, production efficiency and mechanical properties, where recent surveys have been cited hereby to point out the trending topic condition of this research subject.

\section{ACKNOWLEDGMENTS}

This publication is realized with the support of the European Union and the Region Emilia-Romagna (POR-FESR 2014-2020, Axis 1, Research and Innovation) inside the 'IPERCER' project with the aim of developing energy efficient solutions for the production of large porcelain stoneware tiles. Special thanks to KESER ITALIA for providing all the required research infrastructure and materials, and to Pier Paolo Conti for his scientific supervision.

\section{REFERENCES}

[1] Beaumont, P.W.R., Soutis, C. and Hodzic, A.: Structural integrity and durability of advanced composites: Innovative modelling methods and intelligent design, Woodhead Publishing, Cambridge, 2015.

[2] Jawaid, M. and Thariq, M.: Handbook Sustainable Composites for Aerospace Applications, Woodhead Publishing, Cambridge, 2018.

[3] Tsetsekou, A., Agrafiotis, C. and Milias, A.: Optimization of the rheological properties of alumina slurries for ceramic processing applications Part I: Slip-casting, J. of the Eur. Ceram. Soc., Vol. 21(3), pp.363-373, 2001.

[4] Lange, F.F.: Powder processing science and technology for increased reliability, J. Am. Ceram. Soc., Vol. 72(1), pp. 3-15, 1989.

[5] Lee, W.E,,Rainforth, M.: Ceramic microstructures: property control by processing. Springer Science \& Business Media, Berlin, 1994.

[6] Fragassa, C., de Camargo, F.V., Pavlovic, A., Silveira, A.C.F., Minak, G. and Bergmann, C.P. Mechanical Characterization of Gres Porcelain and Low-Velocity Impact Numerical Modeling, Mat., Vol. 11(7), pp.1082, 2018. DOI:10.3390/ma11071082.

[7] Souza, F.D. and Bragança, S.R.: Humic Acid as Dispersant of an Alumina Suspension and its Rheological Behaviour, Mat. Res., Vol. 21(2), 2018.

[8] de Souza, F. and Bragança, S.R.: Extraction and characterization of humic acid from coal for the application as dispersant of ceramic powders, J. of Mat. Res. and Tech., Vol. 7(3), pp.254-260, 2018.

[9] Portillo, C.G., García, A.L. and García V. L.: Rheology of ceramic materials, Bubok Publishing S.L., Valencia, 2011.

[10] Barrachina, E., Llop, J., Notari, M.D., Fraga, D., Martí, R., Calvet, I., Rey, A., Lyubenova, T.S., Kozhukharov, S.V., Kozhukharov, V.S. and Carda,
J.B.: Rheological effect of different deflocculation mechanisms on a porcelain ceramic composition. J. of Chem. Tech. \& Metallurgy, Vol. 50(4), pp.493-502, 2015.

[11] Pavlovic, A., Fragassa, C., Ubertini, F. and Martini, A.: Modal analysis and stiffness optimization: the case of a tool machine for ceramic tile surface finishing, J. of the Serbian Soc. for Comp. Mech., Vol. 10, No. 2, pp. 30-44, 2016.

[12] Fragassa, C.: Limits in Application of International Standards to Innovative Ceramic Solutions, Int. J. for Quality Res., Vol. 9, No. 2, pp. 279-298, 2015.

[13] Fragassa, C.: Flexural Testing Machine as an OffLine Control System for Quality Monitoring in the Production of Bended Ceramic Tiles, Int. J. for Quality Res., Vol. 10, No. 2, pp. 373-388, 2016.

[14] Setz, L.F.G., Koshimizu, L., de Mello-Castanho, S.R.H. and Morelli, M.R.: Rheological analysis of ceramics suspensions with high solids loading, Mat. Sci. Forum, Vol. 727, pp. 646-651, 2012.

[15] Svec, M., Roosen, A., Schmidt, M., Münstedt, H., Betz, T. and Koppe, F.: Rheology and Local Flow Behaviour of Ceramic Slurries in the Tape Casting Head, Key Eng. Mat., Vol. 206-213, pp. 219-222, 2002.

[16]Zhu, X., Jiang, D. and Tan, S.: The control of slurry rheology in the processing of reticulated porous ceramics, Mat. Res. Bulletin, Vol. 37, No. 3, pp. 541-553, 2002.

[17] SACMI Imola: Tecnologia ceramica applicata, La Mandragora, Bologna, 2003.

[18]Eygi, M.S. and Ateşok, G.: An investigation on utilization of poly-electrolytes as dispersant for kaolin slurry and its slip casting properties, Ceram. Int., Vol. 34, pp. 1903-1908, 2008.

[19] Amorós, J.L., Sanz, V. and Jarque, J.C.: Elektrokinetic and rheological properties of highly concentrated kaolin dispersion: influence of particle volume fraction and dispersant concentration, Appl. Clay Sci., Vol. 49, pp. 33-43, 2010 .

[20] Konduri, M.K.R. and Fatehi, P.: Dispersion of kaolin particles with carboxymethylated xylan, Appl. Clay Sci., Vol. 137, pp. 183-191, 2017.

[21] Fragassa, C.: Modelling the viscoelastic response of ceramic materials by commercial Finite Elements codes, FME Trans., Vol. 44, No. 1, pp. 58-64, 2016.

[22] Pavlovic, A. and Fragassa, C.: Modelling the Viscoelasticity of Ceramic Tiles by Finite Element, AIP Conference Proceedings, Vol. 1736, Article number 4949749, 2016.

[23] Andreola, F., Castellini, E., Manfredini, T. and Romagnoli, M.: The role of sodium hexametaphosphate in the dissolution process of kaolinite and kaolin, J. of the Eur. Ceram. Soc., Vol. 24, pp. 2113-2124, 2004. 
[24] Wang, F., Yin, J., Zuo, K., Xia, Y., Yao, D. and Zeng, Y.: Effect of organic additives on mechanical properties of $\mathrm{SiC}$ ceramics prepared by a modified gelcasting method. Proc. and Appl. of Ceram., Vol. 10(4), pp.227-233, 2016.

[25] Hammadi, L.: Improving of the mechanical and rheological properties of slip of ceramic, Constr. and Build. Mat., Vol. 173, pp.118-23, 2018.

[26] Benelli, T., Mazzocchetti, L., D'Angelo, E., Lanzi, M., Saraga, F., Sambri, L., Franchini, M.C. and Giorgini, L.: New nitrogen-rich heterocycles for organo-modified bentonites as flame retardant fillers in epoxy resin nanocomposites, Polym. Eng. and Science, Vol. 57(6), pp.621-630, 2017.

[27] Giorgini, L., Ballardini, S., Benelli, T., Mazzocchetti, L. and Zattini, G.: Dispersion and evaluation of organically modified nanoclays as performance enabling fillers for pPVC synthetic leathers, AIP Conference Proceedings, Vol. 1981, Article number 020155, 2018

[28] Wiecinska, P., Graule, T. and Bachonko, M.: Organic additives in gel-tape casting of ceramic powders - A novel approach to the problem of elasticity and cracking of thin tapes, J. of the Eur. Ceram. Soc., Vol. 35(14), pp.3949-3957, 2015.

[29] Benaglia, M., Alberti, A., Giorgini, L., Magnoni, F. and Tozzi, S.: Poly(glycidyl methacrylate): A highly versatile polymeric building block for post- polymerization modifications. Polymer Chemistry, Vol. 4(1), pp. 124-132, 2013.

\section{NOMENCLATURE}

$T_{g} \quad$ Glass transition temperature

\section{Greek symbols}

$\zeta \quad$ Zeta potential

\section{REŠAVANJE REOLOŠKOG PONAŠANJA KERAMIČKIH MULJA}

\section{С. Витали, Л. Ђорђини}

С обзиром на то да већина сировина које се користе у керамичкој индустрији имају седиментно порекло, њихова формација се води у воденом медију, због чега вес́ина процеса производње керамике укључује воду за производњу различитих полупроизвода. Међутим, реолошко понашање керамике може имати значајан утицај на њихову обраду, дефинишући кључне параметре као што су однос чврсте воде, ниво дефлокулације и количина хемијских адитива које ће ce користити. Стога, предлозени рад истражује сложеност основних аспеката рхеологије у керамичким муљевима, са намером да обезбеди преглед хемијског, физичког и практичног утицаја на израду плочица са индустријских и научних тачака. 